\title{
KEEFEKTIFAN MODEL BERPIKIR INDUKTIF DAN MODEL SAINTIFIK PADA PEMBELAJARAN MENULIS FABEL
}

\author{
Lina Handayani ${ }^{1}$, Evi Chamalah ${ }^{2}$, Leli Nisfi Setiana ${ }^{3}$ \\ Prodi PBSI, FKIP, Universitas Islam Sultan Agung \\ handayanilina41@gmail.com¹, chamalah@unissula.ac.id², lelinisfisetiana@yahoo.co.id³
}

\begin{abstract}
Abstrak
Keterampilan menulis fabel merupakan salah satu pembelajaran di kelas VII SMP Islam Sultan Agung 1 Semarang. Berdasarkan wawancara yang dilakukan peneliti, diketahui bahwa pembelajaran menulis fabel dapat dikatakan masih rendah. Oleh sebab itu, peneliti menggunakan model Berpikir Induktif dan model Saintifik pada pembelajaran menulis fabel. Tujuan penelitian ini yaitu (1) untuk mengetahui perbedaan keterampilan menulis antara kelompok yang menggunaan model Berpikir Induktif dan model Saintifik, (2) untuk mengetahui tingkat keefektifan penggunaan model Berpikir Induktif dan model Saintifik, serta (3) untuk mengetahui perubahan sikap sesudah menggunakan model Berpikir Induktif dan model Saintifik. Metode penelitian yang digunakan adalah metode eksperimen dengan desain posttest only-control group. Sampel yang digunakan dalam penelitian ini adalah kelas VII A sebagai kelompok eksperimen I, kelas VII B sebagai eksperimen II, dan kelas VII C sebagai kelompok kontrol. Hasil penelitian menunjukkan adanya perbedaan keterampilan menulis fabel kelompok eksperimen I dan kelompok eksperimen II. Perbedaan tersebut ditunjukkan dari hasil analisis uji-t data postes kelompok eksperimen I dan kelompok eksperimen II yang menunjukkan $0,588>0,05$ dan 0,600>0,05. Selanjunya, hasil penelitian juga menunjukkan bahwa model Berpikir Induktif lebih efektif dibandingkan dengan model Saintifik. Hal ini dapat dilihat dari selisih nilai rata-rata pada saat postes berlangsung yaitu 80,26 dan 79,09 yang berselisih 1,17. Selain itu, hasil penelitian juga menunjukkan bahwa adanya perubahan sikap siswa sesudah menggunakan model Berpikir Induktif dan model Saintifik. Hal tersebut dapat dilihat pada hasil uji-t sebesar 0,550>0,05 dan $0,541>0,05$.
\end{abstract}

Kata Kunci : menulis fabel, model berpikir induktif, model saintifik.

\begin{abstract}
Fable writing skills is one of the learning in class VII Islamic Junior High School 1 Sultan Semarang. Based on interviews conducted by researchers, it is known that fable writing learning can be said to be still low. Therefore, the researcher uses the model of Inductive Thinking and Scientific model on fable writing lesson. The purpose of this research is (1) to know the difference of writing skill between the groups using the model of Inductive Thinking and the Scientific Model, (2) to know the effectiveness level of using Inductive Thinking Model and Scientific Model, and (3) to know the attitude change after using Thinking Model Inductive and Scientific models. The research method used is experimental
\end{abstract}


method with posttest only-control group design. The sample used in this research is class VII A as experimental group I, class VII B as experiment II, and class VII C as control group. The result of the research shows the difference of writing skill of experiment group I and experiment group II. The difference is shown from the result of t-test analysis of experimental data of experimental group I and experimental group II which shows 0,588>0,05 and 0,600>0,05. Furthermore, the results also show that the Inductive Thinking model is more effective than the scientific model. This can be seen from the difference in the average value at the time of the postes took place that is 80.26 and 79.09 of the dispute 1.17. In addition, the results of the study also showed that there is a change in attitude of students after using the model of Inductive Thinking and Scientific model. It can be seen on t-test result of $0,550>0,05$ and $0,551>0,05$.

Keywords: Writing Fable, Inductive Thinking Model, Scientific Model

\section{PENDAHULUAN}

Pada dasarnya perintah menulis sudah ada sejak zaman dahulu, dimana setiap manusia diajurkan untuk menulis agar apa yang mereka ketahui dapat terekam dalam tulisannya, Allah

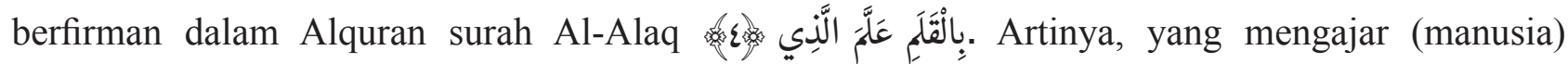
dengan pena. Dalam arti sempit dengan pena segala ilmu pengetahuan dapat dicatat untuk dijadikan pedoman informasi. Dalam arti luas pena dapat dikatakan menyimpan berbagai informasi, mengakses dan menyalurkan secara cepat dan tepat, seperti email, dan lain-lain. Selain terdapat pada Alquran surah Al-Alaq perintah menulis juga terdapat pada Alquran surah Al-Qalam ayat 1 yang berbunyi . Artinya: Nun, demi pena dan apa yang mereka tuliskan. Dimana pena digunakan sebagai alat untuk menulis. Menulis dalam hal ini yaitu mereka bisa menuangkan (pengetahuan, perasaan) ke dalam suatu bentuk tulisan.

Menulis ialah suatu keterampilan berbahasa yang wajib dipahami dan dipelajari oleh siswa. Menulis tidak akan lepas dari tiga keterampilan lainnya yaitu membaca, menyimak dan berbicara. Namun, menulis selalu erat kaitannya dengan membaca. Seperti halnya yang diungkapkan oleh Zainurrahman (2013) menulis ialah penggabungan antara proses pembelajaran dengan keterampilan, maka dapat dikatakan dalam setiap pembelajaran terdapat kegiatan menulis, sama seperti pada keterampilan membaca.

Setelah dilakukannya observasi pada dua guru Bahasa Indonesia di sekolah tersebut, proses kegiatan pembelajaran pada keterampilan menulis masih ada kendala. Beberapa kendala yang terdapat dalam kegiatan pembelajaran diantaranya kurangnya sarana dan prasarana pada sekolah tersebut. Selain itu, sikap sosial siswa bisa dikatakan cukup baik, hal tersebut bisa dilihat dalam kegiatan pembelajaran yang berlangsung meskipun terdapat beberapa siswa yang kurang antusias dalam kegiatan pembelajaran. Sikap tanggung jawab serta disiplin yang ada pada diri siswa bisa dikatakan cukup, hal tersebut terbukti bahwa masih ada beberapa siswa sering terlambat dalam mengumpulkan tugas. Namun, untuk sikap spiritual siswa sudah baik dengan awal pembelajaran dilakukannya tadarus Qur'an dan berdoa sedangkan diakhir pembelajaran mengucapkan hamdallah.

Berdasarkan permasalahan yang terjadi di SMP Islam Sultan Agung 1 Semarang, salah satu materi yang dijadikan penelitian oleh peneliti terdapat pada kompetensi dasar 4.15, yaitu menceritakan 
kembali isi fabel/legenda daerah setempat yang terdapat di kelas VII semester genap Kurikulum 2013. Kompetensi dasar tersebut menekankan agar siswa mampu mengungkapkan isi teks cerita fabel dalam bentuk lisan ataupun tulisan berdasarkan fabel/legenda daerah setempat. Hal tersebut menuntut siswa untuk dapat mencapai indikator-indikator pembelajaran yang telah ditentukan. Adapun indikator pencapaian kompetensinya yaitu siswa mampu memahami pengertian teks cerita fabel berdasarkan fabel/legenda daerah setempat, serta mampu menulis teks cerita fabel dengan memerhatikan aspek kebahasaan dan struktur fabel. Fabel ialah suatu bentuk cerita pendek dimana dalam cerita tersebut terdapat penggambaran watak serta budi pekerti manusia diibaratkan dengan binatang (Wahono 2016).

Dalam teks cerita fabel menceritakan kehidupan sehari-hari manusia yang digambarkan oleh tokoh-tokoh binatang seperti halnya dalam kehidupan nyata. Namun, cerita tersebut bukanlah cerita nyata melainkan cerita rekaan (khayalan). Cerita tersebut dibuat untuk menghibur pembaca atau penonton, selain itu yang paling penting adalah selalu terdapat nilai-nilai karakter yang terdapat di setiap cerita. Sehingga adanya cerita fabel tersebut siswa-siswi dapat belajar tentang pendidikan karakter yang terkandung dalam cerita tersebut. Pendapat peneliti sependapat dengan Radhika (2014) yang mengungkapkan bahwa contoh dongeng Si Kancil mempunyai pesan moral yang sangat banyak. Salah satu pesan moral yang terdapat dalam ceritanya tersebut yaitu tindakan mencuri. Siswa akan terpengaruh dengan cerita tersebut bahwa tindakan mencuri merupakan perbuatan yang tidak baik sehingga bagi siapa saja yang melakukan perbuatan tidak terpuji tersebut akan memperoleh hukuman. Nantinya, saat tumbuh dewasa ia selalu mengingat hal tersebut dan menjauhi perbuatan tidak baik itu. Selain itu, Katsadoros (2011) mengemukakan bahwa dimensi pedagogis yang terdapat pada fabel serta kemampuannya untuk menyampaikan pesan melalui cara yang tidak langsung dan mendorong banyak orang tertarik pada cerita tersebut.

Mengenai materi yang dipilih oleh peneliti maka peneliti harus bisa memilih model serta media yang relevan untuk pembelajaran cerita fabel. Banyak model dan media pembelajaran yang ditawarkan dalam Kurikulum 2013, di mana dalam hal ini guru dituntut untuk menyesuaikan model serta media pembelajaran dengan materi yang diajarkan agar model, media dan materi menjadi relevan. Salah satu model dan media pembelajaran yang dapat digunakan dalam materi menulis fabel ialah model berpikir induktif dan model saintifik dengan media video gubug dongeng yang diaggap peneliti sesuai dengan materi. Model pembelajaran Berpikir Induktif dapat membantu siswa mengumpulkan informasi serta mengujinya dengan teliti, mengolah informasi ke dalam konsep-konsep, dan belajar memanipulasi konsep-konsep tersebut (Joice 2009:102). Model pembelajaran berpikir induktif digunakan secara bertahap, strategi ini juga dapat meningkatkan kemampuan siswa untuk membentuk konsepkonsep secara efisien dan meningkatkan jangkauan persepektif dari sisi mana mereka memandang suatu informasi. Dalam hal ini peneliti sependapat dengan Jayanti (2017) yang mengemukakan bahwa terdapat perbedaan kemampuan menulis antara siswa yang mengikuti model pembelajaran menggunakan model Berpikir Induktif dengan siswa yang menggunakan model konvensional. Siswa yang mengikuti pembelajaran dengan model berpikir induktif lebih terorganisir dalam menyusun fabel berdasarkan unsur-unsur pembangunnya dibandingkan dengan siswa yang mengikuti model pembelajaran konvensional. Aadapun untuk model saintifik Sujawarta (2012) mengemukakan bahwa pembelajaran yang menekankan pada pemberian pengalaman secara langsung baik menggunakan 
pengamatan, percobaan maupun dengan cara yang lainnya, sehingga realitas yang akan berbicara sebagai informasi atau data yang diperoleh selain valid juga dapat dipertanggungjawabkan. Pendapat Suwarni (2016) sejalan dengan Sujarwana (2012) yang mengemukakan bahwa model pembelajaran saintifik berpengaruh positif terhadap kemampuan menulis teks ulasan drama. Pengaruh tersebut dapat dilihat dari keterampilan menulis teks ulasan drama, bahwa dengan diterapkannya model saintifik siswa mejadi lebih terampil dibandingkan dengan pembelajaran menggunakan model konvensional.

Media audio visual ialah suatu cara memaparkan materi dengan alat bantu mesin-mesin mekanis dan elektronik, untuk memaparkan pesan-pesan audio dan visual (Kustandi dan Bambang 2013:30). Salah satu bentuk media audio visual adalah video. Setiana (2015) mengemukakan bahwa media video bisa memberikan rangsangan dan dorongan kepada siswa agar proses pembelajaran menjadi efektif dan efisien. Dengan menggunakan media video inti permasalahan tergambar lebih nyata serta dapat memperjelas permasalahan yang dibahas dalam pembelajaran. Dalam penelitian ini peneliti menggunakan video gubug dongeng guna untuk menstimulus siswa agar lebih mudah memahami dan mempelajari apa yang di sampaikan oleh video tersebut. Gubug dongeng merupakan kumpulan video tentang fabel dan dongeng di mana dalam video tersebut ada beberapa fabel dengan penokohan dan tema yang berbeda. Selain itu, dalam video tersebut disajikan pula banyak pesan moral atau amanat yang bisa dipetik dan dipelajari oleh siswa dalam kehidupan sehari-hari. Dengan adanya permasalahan tersebut, peneliti melakukan penelitian dengan judul "Keefektifan Penggunaan Model Berpikir Induktif dan Model Saintifik pada Pembelajaran Menulis Fabel di Kelas VII SMP Islam Sultan Agung 1 Semarang."

\section{METODE PENELITIAN}

Jenis penelitian yang digunakan dalam penelitian ini yaitu penelitian eksperimen. Desain yang digunakan True Experiment dengan Posttest-Only Control Group. Sampel pada penelitian ini yaitu kelas VII A dengan jumlah 27 siswa sebagai kelompok eksperimen I, kelas VII B mempunyai jumlah 23 siswa sebagai kelompok eksperimen II dan kelas VII C dengan jumlah 23 siswa sebagai kelompok kontrol. Kelompok eksperimen I atau kelas VII A diberikan perlakuan dengan menggunakan model berpikir induktif, kelompok eksperimen II atau kelas VII B diberikan perlakuan dengan menggunakan model Saintifik, dan kelompok kontrol atau kelas VII C tanpa diberikan perlakuan.

\section{Variabel Penelitian}

Variabel dalam penelitian ini ada dua, yaitu variabel terikat dan variabel bebas. Variabel terikat dalam penelitian ini adalah kemampuan menulis fabel kelas VII, sedangkan variabel bebas dalam penelitian ini adalah model berpikir induktif dan model saintifik. Penelitian ini dilakukan pada bulan Maret 2018.

\section{Instrumen}

Istrumen yang digunakan berupa instrumen tes dan nontes. Instrumen tes berupa tes menulis teks fabel, sedangkan instrumen non tes berupa observasi dan dokumentasi. 


\section{Desain Penelitian}

Tahap-tahap pelaksanaan penelitian ini sebagai berikut.

\section{Tahap Eksperimen}

Pada tahap ini kedua kelompok baik eksperimen I ataupun eksperimen II diberikan perlakuan dengan menggunakan model pembelajaran yang berbeda. Berikut tahap-tahap eksperimen yang dilakukan pada kelompok eksperimen dan kontrol.

\section{a. Eksperimen I}

Kelompok eksperimen I merupakan kelompok yang menggunakan model pembelajaran berpikir induktif. Berikut tahap-tahapan pembelajaran dengan model berpikir induktif.

1). Guru menyampaikan informasi kompetensi dasar yang harus dicapai, tujuan pembelajaran, dan langkah pembelajaran yang akan dilaksanakan.

2). Guru menayangkan video cerita fabel Kisah Si Semut dan Induk Ayam.

3). Siswa mengamati video cerita fabel Kisah Si Semut dan Induk Ayam.

4). Siswa mengumpulkan data dengan mencatat pokok-pokok permasalahan yang ada dalam video cerita fabel Kisah Si Semut dan Induk Ayam.

5). Siswa menanyakan hal-hal yang berkaitan dengan video cerita fabel Kisah Si Semut dan Induk Ayam.

6). Siswa menguji data yang diperoleh berkaitan dengan struktur dan kebahasaan video cerita fabel Kisah Si Semut dan Induk Ayam.

7). Guru menayangkan video cerita fabel Kisah Semut dan Merpati.

8). Siswa membangun hipotesis struktur video cerita fabel Kisah Semut dan Merpati.

9). Siswa mengembangkan ide pokok berdasarkan hasil hipotesis.

10). Siswa menulis kembali isi video cerita fabel Kisah Semut dan Merpati.

11). Siswa mempresentasikan hasil menulisnya dan siswa yang lain menanggapinya.

\section{b. Eksperimen II}

Kelompok eksperimen II merupakan kelompok yang menggunakan model pembelajaran saintifik. Berikut tahap-tahapan pembelajaran dengan model saintifik.

1). Guru menyampaikan informasi kompetensi dasar yang harus dicapai, tujuan pembelajaran, dan langkah pembelajaran yang akan dilaksanakan.

2). Guru menayangkan video cerita fabel Kisah Si Musang dan Induk Ayam.

3). Siswa mengamati video cerita fabel Kisah Si Musang dan Induk Ayam.

4). Siswa bertanya jawab mengenai video cerita fabel Kisah Si Musang dan Induk Ayam.

5). Siswa menelaah struktur dan unsur kebahasaan teks cerita fabel pada video Kisah Si Musang dan Induk Ayam. 
6). Guru menayangkan video cerita fabel Kisah Semut dan Merpati.

7). Siswa menulis kembali isi cerita fabel Kisah Semut dan Merpati.

8). Siswa mempresentasikan hasil menulisnya.

\section{HASIL PENELITIAN DAN PEMBAHASAN}

Perbedaan Keterampilan Menulis Teks Cerita Fabel Antara Kelompok Eksperimen I dan Eksperimen II

Perbedaan keterampilan menulis teks cerita fabel antara kelompok yang menggunakan model berpikir induktif dengan kelompok yang diberikan model saintifik pada kegiatan menulis teks cerita fabel dapat diketahui dengan menggunakan rumus uji-t. Adapun hasilnya dapat dilihat pada bagan berikut.

Tabel 1. Uji-t Nilai Postes Keterampilan Menulis Fabel Kelompok Eksperimen I dan

\section{Eksperimen II}

\begin{tabular}{|l|c|r|r|r|r|}
\hline \multicolumn{2}{|c|}{} & \multicolumn{1}{|c|}{ Statistik Grup } \\
\hline \multirow{3}{*}{ Nilai } & Kelompok & N & $\begin{array}{c}\text { Skor } \\
\text { Rata-Rata }\end{array}$ & $\begin{array}{c}\text { Standar } \\
\text { Deviasi }\end{array}$ & \multicolumn{2}{|c|}{ Standar Skor Rata-Rata Kesalahan } \\
\cline { 2 - 7 } & Eksperimen 1 & 27 & 80.26 & 6.131 & 1.180 \\
\cline { 2 - 7 } & Eksperimen 2 & 23 & 79.09 & 8.989 & 1.874 \\
\hline
\end{tabular}

\begin{tabular}{|c|c|c|c|c|c|c|c|c|c|c|}
\hline \multicolumn{11}{|c|}{ Uji Sampel Independen } \\
\hline & & \multicolumn{2}{|c|}{\begin{tabular}{|c} 
Uji Levene untuk \\
$\begin{array}{c}\text { Persamaan } \\
\text { Varian }\end{array}$ \\
\end{tabular}} & \multicolumn{7}{|c|}{ Uji Kesetaraan Skor Rata-Rata } \\
\hline & & \multirow{2}{*}{$\mathrm{F}$} & \multirow{2}{*}{ Sig } & \multirow{2}{*}{$\mathrm{t}$} & \multirow{2}{*}{ df } & \multirow{2}{*}{$\begin{array}{c}\text { Sig } \\
\text { (2-tailed) }\end{array}$} & \multirow{2}{*}{$\begin{array}{c}\text { Perbedaan } \\
\text { Skor Ra- } \\
\text { ta-Rata }\end{array}$} & \multirow{2}{*}{$\begin{array}{l}\text { Standar } \\
\text { Perbedaan } \\
\text { Kesalahan }\end{array}$} & \multicolumn{2}{|c|}{$95 \%$ Interval Perbedaan } \\
\hline & & & & & & & & & Menurun & Meningkat \\
\hline \multirow{2}{*}{ Nilai } & $\begin{array}{l}\text { Varian yang } \\
\text { sama diasum- } \\
\text { sikan }\end{array}$ & 4.179 & .046 & .545 & 48 & .600 & 1.172 & 2.150 & -3.150 & 5.495 \\
\hline & $\begin{array}{l}\text { Varian yang } \\
\text { sama tidak dia- } \\
\text { sumsikan }\end{array}$ & & & .529 & 37.857 & .588 & 1.172 & 2.215 & -3.312 & 5.657 \\
\hline
\end{tabular}

Rata-rata keterampilan menulis teks cerita fabel kelompok eksperimen I sebesar 80,26 dengan nilai terendah 65 dan tertinggi 90. Selanjutnya, nilai rata-rata keterampilan menulis teks cerita fabel kelompok eksperimen II sebesar 79,09 dengan nilai terendah 60 dan tertinggi 91. Hasil yang diproleh menunjukkan perbedaan rata-rata keterampilan menulis teks cerita fabel kelompok eksperimen I dan kelompok eksperimen II tidak berbeda jauh secara signifikan yaitu 1,17. Setelah dilakukan uji-t dua sampel menggunakan SPSS versi 24.0 perbedaan rata-rata yang memperoleh Sig (2-tailed) sebesar 0,600 lebih besar dari 0,05 untuk kelompok eksperimen I dan nilai Sig (2-tailed) 0,588 lebih besar dari 0,05 untuk kelompok ekperimen II. Maka perbedaannya bermakna secara signifikan pada 
probilitas 0,05. Berdasarkan pengujian hipotesis, dapat dikatakan bahwa Ho ditolak dan Ha diterima dalam arti terdapat perbedaan keterampilan menulis teks cerita fabel pada kelompok eksperimen I dan kelompok eksperimen II. Dengan demikian, rata-rata keterampilan menulis teks cerita fabel kelompok eksperimen I lebih baik dibandingkan dengan kelompok eksperimen II. Hal tersebut disebabkan karena pembelajaran dengan menggunakan model berpikir induktif berbantu media video gubug dongeng pada pembelajaran menulis teks cerita fabel merupakan model pembelajaran yang baru bagi siswa. Hal tersebut memberikan pengalaman yang baru bagi siswa disebabkan pada pembelajaran sebelumnya siswa belum pernah diajar dengan menggunakan model tersebut.

\section{Tingkat Keefektifan Penggunaan Model Berpikir Induktif pada Pembelajaran Menulis Teks Cerita Fabel}

Keefektifan penggunaan model berpikir induktif pada pembelajaran menulis teks cerita fabel dalam penelitian ini diketahui dengan nilai rata-rata kelompok tersebut. Adapun hasil perbandingan nilai tersebut dapat dilihat pada tabel berikut.

Tabel 2. Perbandingan Distribusi Frekuensi Kelompok Eksperimen I dan II serta Kelompok Kontrol

\begin{tabular}{|l|r|r|r|r|}
\hline \multicolumn{7}{|c|}{ Statistik } & \\
\hline \multirow{2}{*}{ N } & Pos.Eksperimen_1 & Pos.Eksperimen_2 & Pos.Kontrol \\
\cline { 2 - 6 } & 27 & 23 & 0 \\
\hline Nilai Rata-Rata & 0 & 0 & 71.96 \\
\hline Nilai Tengah & 80.26 & 79.09 & 75.00 \\
\hline Modus & 79.00 & 80.00 & 71 \\
\hline Standar Deviasi & $78^{\mathrm{a}}$ & 80 & 14.313 \\
\hline Minimal & 6.131 & 8.989 & 40 \\
\hline Maksimal & 65 & 60 & 90 \\
\hline a. Nilai terkecil ditampilkan. & 90 & 91 & \\
\hline
\end{tabular}

Berdasarkan hasil perhitungan nilai rata-rata keterampilan menulis teks cerita fabel pada siswa yang diberikan perlakuan dengan menggunakan model berpikir induktif sebesar 80,26 dan nilai ratarata keterampilan menulis teks cerita fabel tanpa diberikan perlakuan sebesar 71,96. Adapun nilai ratarata keterampilan menulis dengan diberikan perlakuan menggunakan model Saintifik sebesar 79,09 dan nilai rata-rata keterampilan menulis teks cerita fabel tanpa diberikan perlakuan sebesar 71,96. Dengan demikian, dari nilai rata-rata dapat disimpulkan bahwa penggunaan model berpikir induktif dan model saintifik sama-sama efektif digunakan dalam pembelajaran menulis teks cerita fabel. Kesimpulan dari penelitian ini yaitu pembelajaran menulis teks cerita fabel dengan menggunakan model berpikir induktif lebih efektif dibandingkan dengan model pembelajaran saintifik. 


\section{Pengaruh Sikap Sesudah Penggunan Model Berpikir Induktif dan Model Saintifik Berbantu Media Video Gubug Dongeng pada Pembelajaran Menulis Teks Cerita Fabel}

Angket dalam pembelajaran menulis teks cerita fabel dilakukan pada saat kegiatan postes berlangsung. Angket sikap belajar siswa digunakan untuk menilai sikap siswa pada saat pembelajaran. Angket diisi oleh siswa yang mengikuti pembelajaran tersebut. Pada angket sikap belajar siswa secara keseluruhan diikuti oleh 50 siswa yang terdiri dari 27 siswa kelompok eksperimen I dan 23 siswa kelompok eksperimen II.

Tabel 3. Uji-t Angket Sikap Keterampilan Menulis Fabel Kelompok Eksperimen I dan Kelompok Eksperimen II

\begin{tabular}{|l|l|r|r|r|r|}
\hline \multicolumn{7}{|c|}{ Statistik Grup } \\
\hline & Kelompok & N & Skor rata-rata & \multicolumn{1}{|c|}{ Standar deviasi } & Standar Skor Rata-Rata Kesalahan \\
\hline \multirow{3}{*}{ Nilai } & Eksperimen 1 & 27 & 81.44 & 8.290 & 1.595 \\
\cline { 2 - 6 } & Eksperimen 2 & 23 & 83.09 & 10.583 & 2.207 \\
\hline
\end{tabular}

\begin{tabular}{|c|c|c|c|c|c|c|c|c|c|c|}
\hline \multicolumn{11}{|c|}{ Uji Sampel Independen } \\
\hline & & \multicolumn{2}{|c|}{$\begin{array}{l}\text { Uji Levene untuk } \\
\text { Persamaan Varian }\end{array}$} & \multicolumn{7}{|c|}{ Tes Kesetaraan Skor Rata-Rata } \\
\hline & & \multirow{2}{*}{$\mathrm{F}$} & \multirow{2}{*}{ Sig } & \multirow{2}{*}{$\mathrm{t}$} & \multirow{2}{*}{ df } & \multirow{2}{*}{$\underset{\text { (2-tailed) }}{\text { Sig }}$} & \multirow{2}{*}{$\begin{array}{c}\text { Perbedaan } \\
\text { Skor rata-Rata }\end{array}$} & \multirow{2}{*}{$\begin{array}{c}\text { Standar } \\
\text { Perbedaan } \\
\text { Kesalahan }\end{array}$} & \multicolumn{2}{|c|}{$95 \%$ Interval perbedaan } \\
\hline & & & & & & & & & Menurun & meningkat \\
\hline \multirow{2}{*}{ Nilai } & $\begin{array}{l}\text { Varian yang sama } \\
\text { diasumsikan }\end{array}$ & 1.970 & .167 & -.615 & 48 & .550 & -1.643 & 2.670 & -7.011 & 3.726 \\
\hline & $\begin{array}{l}\text { Varian yang sama } \\
\text { tidak diasumsikan }\end{array}$ & & & -.603 & 41.431 & .541 & -1.643 & 2.723 & -7.140 & 3.855 \\
\hline
\end{tabular}

Dari hasil angket diketahui bahwa skor rata-rata kelompok eksperimen I sebesar 81,44 dan standar deviasi 8,290, sedangkan skor rata-rata kelompok eksperimen II sebesar 83,09 dengan standar deviasi 10,583. Artinya perubahan sikap siswa sesudah penggunaan model Bepikir induktif dan model saintifik dalam kriteria baik. Selain itu, angket sikap belajar siswa juga diuji dengan menggunakan uji idenpendent sample test. Hasil yang diperoleh pada uji tersebut yaitu Sig (2-tailed) sebesar 0,550 lebih besar dari 0,05 untuk kelompok eksperimen I sedangkan Sig (2-tailed) sebesar 0,541 lebih besar 0,05 untuk kelompok eksperimen II. Artinya jika nilai Sig (2-tailed) lebih besar 0,05 maka dapat dikatakan bahwa terdapat perubahan sikap siswa sesudah menggunakan model Berpikir Induktif dan model Saintifik berbantu media video Gubug Dongeng pada pembelajaran menulis teks cerita fabel.

\section{PENUTUP}

Simpulan pada penelitian ini yang dilaksanakan mendapatkan hasil sebagai berikut.

1. Hasil perbedaan keterampilan menulis kelompok eksperimen I dan kelompok eksperimen II diperoleh nilai Sig. (2-tailed) sebesar 0,600>0,05 dan 0,588>0,05. Berdasarkan pengujian hipotesis dapat dikatakan bahwa Ho ditolak dan Ha diterima dalam arti nilai rata-rata model 
berpikir induktif lebih baik dibandingkan dengan model saintifik.

2. Hasil penelitian keterampilan menulis teks cerita fabel pada siswa yang menggunakan model pembelajaran berpikir induktif terdapat perbedaan yang tidak terlalu signifikan dengan siswa yang menggunakan model pembelajaran saintifik. Di mana pada nilai rata-rata keterampilan menulis teks cerita fabel pada kelompok eksperimen I sebesar 80,26, sedangkan pada kelompok eksperimen II sebesar 79,09. Adapun selisih postes antara kelompok eksperimen I dan kelompok eksperimen II sebesar 1,17. Hal ini menunjukkan bahwa Ha diterima dan Ho ditolak dengan arti model pembelajaran berpikir induktif lebih efektif dibandingkan dengan model pembelajaran saintifik.

3. Dari hasil angket siswa diketahui bahwa siswa mengalami perubahan sikap sesudah diberikan model pembelajaran berpikir induktif dan model pembelajaran saintifik. Berdasarkan perhitungan angket dengan menggunakan operasi komputer uji-t diketahui 0,550 lebih besar dari 0,05 untuk kelompok eksperimen I dan 0,541 lebih besar dari 0,05 untuk kelompok eksperimen II. Artinya, bahwa terdapat perubahan sikap siswa sesudah menggunakan model berpikir induktif dan model saintifik pada pembelajaran menulis fabel di kelas VII SMP Islam Sultan Agung 1 Semarang. Hal ini menunjukkan bahwa perubahan sikap kelompok yang diberikan perlakuan dengan menggunakan model berpikir induktif lebih baik dibandingkan dengan perubahan sikap kelompok yang menggunakan model saintifik.

\section{DAFTAR PUSTAKA}

Jayanti, Aninda Kusuma. 2017. "Keefektifan Model Pembelajaran Berpikir Induktif dalam Pembelajaran Menulis Teks Fabel pada Siswa Kelas VII SMP Negeri 1 Yogyakarta”. Journal Student UNY

Joice, Bruce, et.al. 2009. Models Of Teaching Model-Model Pengajaran. Yogyakarta: Pustka Pelajar. Edisi Kedelapan.

Katsadoros, George C. 2011. "Aesopic Fables in the European and the Modern Greek Enlightenment". Review of European Studie, Volume.3, No.2, Desember

Radhika, F. 2014. "Keefektifan Penggunaan Model Example Non-Example dalam Pembelajaran Menulis Teks Fabel pada Siswa Kelas VIII SMP Negeri 6 Magelang”. Skripsi. Universitas Negeri Yogyakarta.

Setiana, Leli Nisfi. 2015. Model Simulasi Kreatif Berbantu Media Video Sebagai Alternatif Pembelajaran Inovatif. Seminar Nasional Pendidikan Bahasa Indonesia 2015. ISSN: 2477$636 \mathrm{X}$. 
Sujarwata, Agus. 2012. Mengkondisikan Pembelajaran IPA dengan Pendekatan Saintifik. Jurnal Nuansa Kependidikan Volume.16, No.1

Suwarni, Titik. 2016. Pengaruh Pendekatan Saintifik Terhadap Kemampuan Menulis Teks Ulasan Drama Siswa Kelas XI SMK Negeri 8 Medan Tahun Pembelajaran 2014/2015. Jurnal Basastra, Volume.5, No. 1, 2016

Wahono, et.al. 2016. Mahir Berbahasa Indonesia untuk SMP/MTs Kelas VII. Jakarta: Erlangga.

Zainurrahman. 2013. Menulis Dari Teori Hingga Praktik (Penawar Racun Plagiarisme). Bandung: Alfabeta. 